Mete Feridun $^{1}$

UDK 330.14:336.743>(560)

ORIGINAL SCIENTIFIC PAPER

IZVORNI ZNANSTVENI RAD

\title{
CAPITAL REVERSALS AND EXCHANGE MARKET PRESSURE: EVIDENCE FROM THE AUTOREGRESSIVE DISTRIBUTED LAG (ARDL) BOUNDS TESTS
}

\begin{abstract}
This article examines the relationship between capital reversals and exchange market pressure in Turkey within an autoregressive distributed lag (ARDL) bounds testing and Granger causality framework using monthly data from 1991:12 to 2006:08. The results suggest that capital reversals are in a long-run equilibrium relationship with exchange market pressure. Granger causality tests indicate that there exists short-run and long-run causality running from capital reversals to exchange market pressure, but not vice versa. These findings lend empirical support to the Sudden Stop theory.
\end{abstract}

JEL Classification: F31, G14

Key words: capital reversals, exchange market pressure, Turkey, ARDL

\section{INTRODUCTION}

It is widely acknowledged that the IMF-led financial liberalization policies have exposed emerging market economies to short-term speculative capital movements and to currency crises. The mechanisms through which a sudden stop or reversal in capital flows may lead to a currency crisis have been explained through the sudden stop theory suggested by Calvo (1998) and Calvo et al. (2003). Despite the developments on the theoretical front and substantial policy interest, there is surprisingly little empirical literature testing the validity of the sudden stop hypothesis in emerging markets. The related empirical literature has documented evidence of the role played by capital flows in the upsurge of currency crises (See, for example, Kaminsky and Reinhart, 1999; Gazioglu, 2003; Komulainen and Lukkarila, 2003). However, no study to date has focused on the direct causal effects of capital reversals on exchange market pressure.

The present article aims at filling this gap in the literature through investigating the validity of the sudden stop theory in Turkey. In addition, it offers a contribution to the existing literature on the methodological front by applying the autoregressive distributed lag (ARDL) bounds testing procedure (Pesaran, et al. 2001) to investigate the short-run and long-run causal effects of capital reversals on exchange market pressure (hereafter EMP), which has not been done to date. This is a novel approach as the ARDL methodology allows inclusion of a stationary, $I(0)$ EMP index in the analysis while the conventional cointegration techniques can only accommodate $I(1)$ series.

\footnotetext{
${ }^{1}$ Department of Banking and Finance, Faculty of Business and Economics, Eastern Mediterranean University, Gazi Magosa, North Cyprus, Mersin 10 Turkey, E-mail: mete.feridun@emu.edu.tr
} 
It has been widely argued that Turkish economy became vulnerable to speculative pressure and currency crises after liberalizing capital flows in August, 1989 (See, for instance, Yeldan 1998, Alper 2001, Ekinci 2002). Indeed, thereafter, Turkish economy experienced currency crises in 1994 and 2001, as well as a number of unsuccessful speculative attacks which where fended off by the intervention of the Turkish Central Bank. The present article studies the Turkish experience with capital outflows for three reasons. First, it is a small open economy in which world prices and global monetary conditions can be taken as given. This is an assumption underlying most of the theoretical speculative attack models in the literature and makes Turkey a case study representing other emerging market economies. Second, the Turkish economy is unique case as the sample period includes various unique types of exchange rate regimes. In particular, the currency crisis of 1994 differed from the crises experienced in other emerging economies as it erupted in midst of a managed-float, rather than a pegged exchange rate regime. Third, over $60 \%$ of the capitalization of the Istanbul Stock Exchange (ISE) is owned by the foreigners. ${ }^{2}$ Therefore, the economy is highly sensitive to capital reversals. From a policy perspective, an econometric analysis of such an economy could offer policy implications not only for Turkish policy-makers, but also for their peers in other emerging economies as the crises are known to have spillover effects in global financial markets.

The rest of the article is structured as follows. The next section will provide the theoretical framework of the study. Section III will introduce the data and explain the empirical methodology. Section IV will point out the conclusions and the policy implications that emerge from the analysis.

\section{THEORETICAL FRAMEWORK}

The empirical application in the present article is based on the parsimonious sudden stop model introduced by Calvo (1998). The model lays out basic mechanisms, whereby a sudden stop and/or a reversal in capital flows may trigger speculative attacks which, in turn, may lead to currency crises. The model suggests the following accounting identity in a non-monetary economy:

$K I=C A D$

where $K I$ and $C A D$ stand for capital inflows and current account deficit in tradable goods, respectively. The following identity holds for both a monetary and non-monetary economy:

$C A D=A D-G N P=D T-G D P T-N F T A$

where $A D, D T, G N P, G D P T$, and NFTA are, respectively, aggregate demand, demand for tradables, gross national product, gross domestic product of tradables and net factor transfers abroad. During a capital inflows episode, $K I$ increases sharply. By Equation 1, this leads to an increase in $C A D$. Therefore, a sudden stop in $K I$ causes a sudden contraction in $C A D$ which, by Equation 2, can be accommodated by lowering the demand for tradable goods with no output cost. However, given the real exchange rate, lower $D T$ is likely to be accompanied by a lower demand for nontradable goods, $A D$ - DT. If it is assumed that prices are flexible, then a decline in the relative price of non-tradables with respect to tradables leads to an increase in real exchange rate. Since a sudden stop is largely unexpected, loans to the non-tradable sector such as real estate extended under the assumption that previous relative prices would remain

\footnotetext{
${ }^{2}$ See Berument et al (2007).
} 
constant could become non-performing, leading to possible bankruptcies. The model also suggests an account of the monetary economy as:

$K I=C A D+R A$

where $K I, C A D$ and $R A$ stand for capital inflows, current account deficit and for accumulation of international reserves per unit of time, respectively. A slowdown in capital inflows and the output/credit collapse associated with this are mitigated by the Central Bank through exhausting international reserves. However, Calvo (1998) argues that this may not be the case in practice. He points out the following central bank balance-sheet identity (in terms of tradable goods):

$R=H-N D A$

where $R, H$ and $N D A$ denote, respectively, international reserves, high-powered money, and net domestic assets (the central bank's certificates of deposit and net worth, and government's deposits at the central bank). Calvo (1998) explains that, in practice, $R$ is likely to increase as a result of the expansion in $H$ and certificates of deposit, but also as a result of an increase in government deposits. In case of an endogenous fall in $K I$, the economy would go through the same type of adjustment as in the non-monetary case if the central bank sticks to its reserves. Calvo (1998) explains that a capital inflows slowdown causes an increase in domestic interest rates. Thus, the central bank has to increase $N D A$ (through a discount window, for example) to cushion the interest rate rise. Keeping international reserves constant, a higher NDA results in an increase in $H$, and in a devaluation, i.e., a rise in the nominal exchange rate. In order for the mechanism to work, the central bank will have to intervene in the foreign exchange market and release international reserves. This mechanism makes the central bank vulnerable to a speculative attack if there is a commitment to a fixed or semi-fixed exchange rate. Reserve-loss policies induce a further flight from domestic assets. This is because, as soon as the public perceives the trouble, they will lower their demand for assets denominated in domestic currency. The rush out of domestic currency assets exacerbate the fall in $K I$ and lead to further pressure in the exchange market.

\section{DATA AND METHODOLOGY III.I. DATA}

The present study employs seasonally-unadjusted monthly data spanning the period 1991:122006:08. The series have been obtained from IMF International Financial Statistics Database of the IMF, and the Central Bank of the Republic of Turkey Electronic Data Delivery System and have been transformed into logarithms. Appendix I gives detailed information about the sources of the data.

\section{III.I.I EXCHANGE MARKET PRESSURE INDEX}

In a floating exchange rate regime, EMP is measured easily because the exchange rate change fully reflects the pressure on the exchange rate. However, in the case of a pegged exchange rate, the exchange rate change alone does not sufficiently reflect the pressure. In this case, speculative attacks on the exchange rate will be reflected through the action taken by the 
monetary authorities. For instance, in order to prevent depreciation of the currency, the central bank may either sell international reserves and/or increase the interest rates.

Eichengreen et al. (1995) suggests a model-independent EMP index which is applicable under all exchange rate regimes. The index consists of weighted average of normalized changes in the exchange rate, the ratio of international reserves to $\mathrm{M} 1$, and the nominal interest rates. The EMP in period $t$ is calculated as follows:

$$
E M P_{\mathrm{t}}=\alpha \Delta \mathrm{e}_{\mathrm{t}}+\beta \Delta\left(\mathrm{i}_{\mathrm{t}}-\mathrm{i}_{\mathrm{t}}\right)-\gamma \Delta\left(\mathrm{r}_{\mathrm{t}}-\mathrm{r}_{\mathrm{t}}\right)
$$

where $\alpha, \beta$ and $\gamma$ are the weights which, are the inverse of the standard deviation of $e_{t},\left(i_{t}-i_{t}\right)$ and $\left(\mathrm{r}_{\mathrm{t}}-\mathrm{r}_{\mathrm{t}}\right)$, respectively. They are used to equalize the volatilities of the three components and to prevent the component with the highest volatility from dominating the index (Eichengreen et $a l .1995) . \Delta$ denotes monthly percent change. $e_{t}$ denotes the equally weighted Turkish lira/Deutsche mark ${ }^{3}$-Turkish lira/US dollar nominal exchange rate basket, $i$ denotes the domestic interest rate (3-month deposit rate) ${ }^{4}, \mathrm{i}_{\mathrm{t}}{ }_{\mathrm{t}}$ corresponds to the same variable but for the US (3-month US T-Bill rate). $r_{, t}$ denotes the ratio of international reserves (net of gold) to M1 for Turkey and, $r_{t}^{*}$ denotes the same ratio for the US. A positive value of the index indicates a increased pressure in the exchange market that can stem from any combination of a devaluation, an expansion of the interest rate spread, or a loss of international reserves.

\section{III.I.II. EXPLANATORY VARIABLES}

Two series are calculated to proxy for short-term capital reversals. The first one (KO1) is a broad measure and involves the measure of capital inflows suggested by (Saxena, 2004). It is calculated as:

$K O 1=-(F A+N E E)$

where FA and NEE denote, respectively, the financial account and net errors and omissions in the balance of payments accounts.

The second series (KO2) is a narrow measure of capital outflow suggested by (Alper and Saglam, 2001). It is calculated as:

$K O 2=-(P I+O S T C)$

where PI and OSTC denote the portfolio investment and the other short-term capital in the balance of payments accounts.

Based on the theoretical framework presented in Section II, an increase in $\mathrm{KO} 1$ and $\mathrm{KO} 2$ are expected to cause an increase the EMP, higher values of which reveal a greater pressure on the domestic currency that can be signaled by a nominal depreciation or a successful defense where the exchange rate remains unchanged but the monetary authorities deter an attack by a combination of interest rate increases and foreign market interventions.

\footnotetext{
${ }^{3}$ For the sake of consistency, we consider Deutsche mark for the whole period under study and use the official fixed parity $(1$ euro $=1.95583$ Deutsche mark) to recalculate Turkish lira/Deutsche Mark exchange rate.

${ }^{4} 3$-month deposit rate has been used as a proxy for short-term interest rates for Turkey as 3-month T-Bill rates are not available for Turkey.
} 


\section{III.II. METHODOLOGY}

In order to investigate the long-run equilibrium relationship between EMP and the capital reversal variables, $K O 1$ and $K O 2$, the ARDL bounds test (Pesaran et $a l, 2001$ ) is applied. One of the advantages of the ARDL bounds test is that it yields valid results regardless of the orders of integration of the underlying variables provided that they are not $I(2)$ or higher (Pesaran et al, 2001). The ARDL model takes into account a one-period lagged error correction term, which does not have restricted error corrections. Hence, it involves estimating the following Unrestricted Error Correction Model (UECM):

$$
\Delta E M P=\alpha_{\mathrm{o}}+\alpha_{1} t+\sum_{i=1}^{m} \alpha_{2} \Delta E M P_{t-i}+\sum_{i=0}^{m} \alpha_{3} \Delta K O 1_{t-i}+\alpha_{4} E M P_{t-1}+\alpha_{5} K O 1_{t-1}+\eta_{i}
$$

where $t$ is time trend variable. On the other hand, $\eta$ and $\mu$ are error terms in the models. The first part of both equations with $\alpha_{2}, \alpha_{3}$ and $\beta_{2}, \beta_{3}$ represents the short-run dynamics of the models whereas the second part with $\alpha_{4}, \alpha_{5}$ and $\beta_{4}, \beta_{5}$ represent the long-run phenomenon. The null hypothesis is $\alpha_{4}=\alpha_{5}=0$, which means the non-existence of the long-run relationship and vice versa.

The ARDL model testing procedure starts with conducting the bounds test for the null hypothesis of no cointegration. The calculated statistics are compared with the critical value tabulated by Pesaran et al. (2001). If the test statistic exceeds the upper critical value, the null hypothesis of no long-run relationship can be rejected regardless of whether the underlying orders of integration of the variables are $I(0)$ or $I(1)$. Similarly, if the test statistic falls below the lower critical value, the null hypothesis is not rejected. However, if the sample test statistic falls between these two bounds, the result is inconclusive. The model can be selected using the lag length criteria like Schwartz-Bayesian Criteria (SBC) and Hannan-Quinn (HQ) information criterion.

The third stage includes conducting standard Granger causality tests augmented with a lagged error-correction term. The Granger representation theorem suggests that there will be Granger causality in at least one direction if there exists co-integration relationship among the variables provided the variables are integrated order of one. Engle-Granger (1987) cautioned that if the Granger causality test is conducted at first difference through vector auto regression (VAR) method than it will be misleading in the presence of co-integration. Therefore, an inclusion of an additional variable to the VAR method such as the error-correction term would help us to capture the long-run relationship. To this end, an augmented form of Granger causality test is involved to the error-correction term and it is formulated in a bivariate $p$ th order vector error-correction model (VECM) which is as follows:

$$
\left[\begin{array}{l}
\Delta E M P_{t} \\
\Delta K \mathrm{a}_{t}
\end{array}\right]=\left[\begin{array}{l}
k_{1} \\
k_{2}
\end{array}\right]+\sum_{i=1}^{p}\left[\begin{array}{ll}
d_{11}(L) & d_{12}(L) \\
d_{21}(L) & d_{22}(L)
\end{array}\right]\left[\begin{array}{l}
\Delta E M P_{t-i} \\
\Delta K \mathrm{a}_{t-i}
\end{array}\right]+\left[\begin{array}{l}
\gamma_{1} E C T_{t-1} \\
\lambda_{1} E C T_{t-1}
\end{array}\right]+\left[\begin{array}{l}
C_{1} \\
C_{2}
\end{array}\right]+\left[\begin{array}{l}
\eta_{1} \\
\eta_{2}
\end{array}\right]
$$

where $\Delta$ is a difference operator, ECT representing the error-correction term derived from long-run co-integrating friendship via ARDL model, $\mathrm{C}(\mathrm{i}=1,2)$ is constant and $\eta(i=1,2)$ are serially uncorrelated random disturbance term with zero mean. The significance of the 
differenced explanatory variables based on F-statistics indicates the existence of short-term causal effects, whereas, the significance of the estimated lagged error correction term $\left(\mathrm{ECT}_{\mathrm{t}-1}\right)$ based on t-statistics indicates the existence of a long-term relationship (Narayan and Smyth, 2004). The rejection of the null hypothesis under investigation by both the F-value and the $t-$ value would indicate that the explanatory variable Granger causes the explained variable both in the long-run and the short-run.

\section{Empirical Results}

In order to make sure that all series are either $I(0)$ or $I(1)$, Augmented Dickey-Fuller (ADF) and more powerful Phillips-Perron (PP) tests are used. In the tests, the lag length and the bandwith are selected with Akaike Information Criterion (AIC) and the Newey-West Bartlett kernel, respectively. Table 1 reports the results of the unit root tests. Two tests generally seem to yield conclusive evidence that the series are stationary, i.e. $I(0)$. The tests give conflicting results in the case of $\mathrm{KO} 2$, possibly due to the differences in the powers of the tests and to the arbitrary nature of lag length selection criteria (Bender et al, 2006). However, the ARDL bounds test is applicable as it yields consistent estimates of the long-run coefficients that are asymptotically normal regardless of whether the underlying variables are $I(1)$ or $I(0)$ (Pesaran et $a l, 2001)$.

Table 1.

\begin{tabular}{|c|c|c|c|c|c|c|}
\hline \multicolumn{7}{|c|}{ ADF and PP Tests for Unit Root } \\
\hline Statistics (Levels) & EMP & Lag & KO1 & Lag & $\mathrm{KO} 2$ & Lag \\
\hline$\tau_{\mathrm{T}}(\mathrm{ADF})$ & $-8.83 *$ & $(1)$ & $-3.58 * *$ & $(2)$ & -2.11 & $(11)$ \\
\hline$\tau_{\mu}(\mathrm{ADF})$ & $-8.44 *$ & $(0)$ & $-3.21 * *$ & $(2)$ & -1.57 & $(11)$ \\
\hline$\tau(\mathrm{ADF})$ & $7.10 *$ & $(0)$ & $-2.78^{*}$ & $(2)$ & -0.12 & $(11)$ \\
\hline$\tau_{\mathrm{T}}(\mathrm{PP})$ & $-9.95 *$ & $(4)$ & $-7.99 *$ & $(7)$ & $-14.60 *$ & $(2)$ \\
\hline$\tau_{\mu}(\mathrm{PP})$ & $-9.98 *$ & $(4)$ & $-7.21 *$ & $(7)$ & $-13.14^{*}$ & $(7)$ \\
\hline$\tau(\mathrm{PP})$ & $\begin{array}{c}- \\
10.01 *\end{array}$ & $(4)$ & $-6.45^{*}$ & (7) & -7.82 & $(8)$ \\
\hline \multicolumn{7}{|c|}{ Statistics (First Differences) } \\
\hline$\tau_{\mathrm{T}}(\mathrm{ADF})$ & $-8.69 *$ & $(8)$ & $-16.86^{*}$ & $(1)$ & $-9.52 *$ & $(10)$ \\
\hline$\tau_{\mu}(\mathrm{ADF})$ & $-8.32 *$ & $(3)$ & $-16.91^{*}$ & $(1)$ & $-9.55^{*}$ & $(10)$ \\
\hline$\tau(\mathrm{ADF})$ & $-6.97 *$ & (3) & $-16.96^{*}$ & (1) & -9.57 & (10) \\
\hline$\tau_{\mathrm{T}}(\mathrm{PP})$ & $\begin{array}{c}- \\
58.87 *\end{array}$ & $(75)$ & $-27.52 *$ & (9) & $-123.63 *$ & $(74)$ \\
\hline$\tau_{\mu}(\mathrm{PP})$ & $55.13 *$ & (74) & $-27.65^{*}$ & (9) & $-122.89 *$ & $\begin{array}{c}(174 \\
)\end{array}$ \\
\hline$\tau(\mathrm{PP})$ & $\begin{array}{c}- \\
52.34 *\end{array}$ & (74) & $-27.68 *$ & (9) & $-126.20^{*}$ & $\begin{array}{c}(174 \\
)\end{array}$ \\
\hline Decision & $\mathrm{I}(0)$ & & $\mathrm{I}(0)$ & & $\mathrm{I}(0)$ & \\
\hline
\end{tabular}

Notes: $\tau_{\mathrm{T}}$ represents the most general model with a drift and trend; $\tau_{\mu}$ is the model with a drift and without trend; $\tau$ is the most restricted model without a drift and trend. Numbers in brackets are the lag lengths and the bandwidths. ${ }^{*},{ }^{* *}$ and ${ }^{* * *}$ denote $^{\circ}$ rejection of the null hypothesis at the $10 \%, 5 \%$ and $1 \%$ levels respectively.

As Pesaran et al. (2001) suggests, the ARDL bounds tests have non-standard distributions. Therefore, the estimated ARDL test statistic is compared to two asymptotic critical values reported in Pesaran et al. (2001) rather than the conventional critical values. Pesaran et al. (2001) discuss five cases with different restrictions on the trends and intercepts and estimate 
critical bounds. The present study considers three of these cases. Table 2 shows the asymptotic critical values reported in Pesaran et al. (2001).

Table 2.

Critical Value Bounds for ARDL Test

\begin{tabular}{|c|c|c|c|c|c|c|}
\hline & \multicolumn{2}{|c|}{0.10} & \multicolumn{2}{c|}{0.05} & \multicolumn{2}{c|}{0.01} \\
\hline Case & $\mathrm{I}(0)$ & $\mathrm{I}(1)$ & $\mathrm{I}(0)$ & $\mathrm{I}(1)$ & $\mathrm{I}(0)$ & $\mathrm{I}(1)$ \\
\hline $\mathrm{F}_{\eta}$ & 3.17 & 4.14 & 3.79 & 4.85 & 5.15 & 6.36 \\
\hline $\mathrm{F}_{\theta}$ & 3.38 & 4.02 & 3.88 & 4.61 & 4.99 & 5.85 \\
\hline $\mathrm{F}_{\pi}$ & 4.19 & 5.06 & 4.87 & 5.85 & 6.34 & 7.52 \\
\hline $\mathrm{t}_{\eta}$ & -2.57 & -3.21 & -2.86 & -3.53 & -3.43 & -4.10 \\
\hline $\mathrm{t}_{\pi}$ & -3.13 & -3.63 & -3.41 & -3.95 & -3.96 & -4.53 \\
\hline
\end{tabular}

Source: Pesaran et al. (2001): pp. 300-304.

If the test statistic is above an upper critical value, the null hypothesis of no long-run relationship can be rejected regardless of the orders of integration of the underlying variables. The opposite is the case if the test statistic falls below a lower critical value. If the sample test statistic falls between these two bounds, the result is inconclusive. Table 3 reports the results of equations 6 and 7 for each of the hypothesized relationships. The representation of the tested hypotheses is such that $\mathrm{F}_{\mathrm{EMP}}(\mathrm{EMP} \mid \mathrm{KO} 1)$ denotes the null hypothesis $\mathrm{H}_{0}: \sigma_{1 \mathrm{EMP}}=\sigma_{2 \mathrm{EMP}}$ $=0$, where $\mathrm{KO} 1$ is a long-run forcing variable for EMP, whereas, $\mathrm{F}_{\mathrm{KO}}(\mathrm{KO} 1 \mid \mathrm{EMP})$ represents the opposite case where the null hypothesis is $\mathrm{H}_{0}: \omega_{1 \mathrm{KO} 1}=\omega_{2 \mathrm{KO} 1}=0$, i.e. EMP is a long-run forcing variable for KO1. In each case, the optimum lag length $(p)$ selection is based on minimizing Akaike Information Criterion (AIC) and Bayesian Information Criterion (BIC).

Table 3.

ARDL Bounds Test

\begin{tabular}{|c|c|c|c|c|c|c|c|}
\hline & & \multicolumn{3}{|c|}{$\begin{array}{l}\text { With Deterministic } \\
\text { Trends }\end{array}$} & \multicolumn{2}{|c|}{$\begin{array}{c}\text { Without } \\
\text { Deterministic } \\
\text { Trend }\end{array}$} & \multirow{2}{*}{$\begin{array}{l}\text { Conclusio } \\
\text { n } \\
\mathrm{H}_{\mathrm{o}}\end{array}$} \\
\hline Hypothesis & $p$ & $\mathrm{~F}_{\theta}$ & $\mathrm{F}_{\pi}$ & $\mathrm{t}_{\pi}$ & $F_{\eta}$ & $t_{\eta}$ & \\
\hline EMP and RER & (1) & & & & & & \\
\hline $\begin{array}{c}\mathrm{F}_{\mathrm{EMP}} \\
(\mathrm{EMP} \mid \mathrm{KO} 1)\end{array}$ & & $19.61 *$ & $\begin{array}{c}16.91 \\
*\end{array}$ & $-8.92 *$ & $\begin{array}{c}18.54 \\
*\end{array}$ & $-8.47 *$ & Reject \\
\hline $\begin{array}{c}\mathrm{F}_{\mathrm{KO} 1} \\
\text { (KO1|EMP) }\end{array}$ & & $13.04 *$ & $\begin{array}{c}10.84 \\
*\end{array}$ & $-5.61 *$ & $\begin{array}{c}12.36 \\
*\end{array}$ & $-5.35 *$ & Reject \\
\hline EMP and BSFI & $(1)$ & & & & & & \\
\hline $\begin{array}{c}\mathrm{F}_{\mathrm{EMP}} \\
(\mathrm{EMP} \mid \mathrm{KO} 2)\end{array}$ & & $24.56^{*}$ & $\begin{array}{c}14.55 \\
*\end{array}$ & $-8.71 *$ & $\begin{array}{c}20.30 \\
*\end{array}$ & $-8.36^{*}$ & Reject \\
\hline $\begin{array}{c}\mathrm{F}_{\mathrm{KO} 2} \\
(\mathrm{KO} 2 \mid \mathrm{EMP})\end{array}$ & & $16.89 *$ & $\begin{array}{c}20.51 \\
*\end{array}$ & $-9.43 *$ & $\begin{array}{c}15.08 \\
* \\
\end{array}$ & $-8.03 *$ & Reject \\
\hline
\end{tabular}

Notes: * indicates that the statistic lies above the 0.05 upper bound.

Results suggest the rejection of the null hypothesis of no long-run relationship in each case regardless of whether is the dependent variable or not. Therefore, it is concluded that EMP is in a long-run equilibrium level relationship with both $\mathrm{KO} 1$ and $\mathrm{KO} 2$ over the sample period. However, as far as a causal relationship is concerned, this is only a necessary but not a 
sufficient condition (Morley, 2006). Groenewold and Tang (2007) suggest that Granger causality tests are applicable regardless of the orders of integration of the underlying variables if it has been established that there exists a long-run equilibrium relationship between the underlying series. Therefore, the existence of the causal relationship is tested using Granger causality tests. Table 4 summarizes the result of the short-run and long-run Granger causality tests within the VECM. Rather than following the mainstream lag length selection criteria, VECMs are estimated for up to 4 lags to make sure that the results are not sensitive to the choice of the lag length (See Katircioglu, 2009). VECMs satisfy the diagnostic tests for serial correlation, functional form misspecification, non-normality and heteroscedasticity ${ }^{5}$.

Table 4.

\begin{tabular}{|c|c|c|c|c|c|c|c|c|}
\hline \multicolumn{9}{|c|}{ Results of Granger Causality Tests based on VECM } \\
\hline & \multicolumn{2}{|c|}{$p=1$} & \multicolumn{2}{|c|}{$p=2$} & \multicolumn{2}{|c|}{$p=3$} & \multicolumn{2}{|c|}{$p=4$} \\
\hline $\begin{array}{l}\text { Direction of } \\
\text { Causation }\end{array}$ & $\alpha$ & $E C T_{t-1}$ & $\alpha$ & $E C T_{t-1}$ & $\alpha$ & $E C T_{t-1}$ & $\alpha$ & $E C T_{t-1}$ \\
\hline $\begin{array}{l}\text { (1) } \mathrm{KO} 1 \\
\rightarrow \mathrm{EMP}\end{array}$ & $\begin{array}{l}-0.70 * \\
(-7.98)\end{array}$ & $\begin{array}{c}0.00^{*} \\
(- \\
26.47)\end{array}$ & $\begin{array}{l}-0.70^{*} \\
(-6.67\end{array}$ & $\begin{array}{c}0.00^{*} \\
(16.11)\end{array}$ & $\begin{array}{l}-0.66^{*} \\
(-5.53)\end{array}$ & $\begin{array}{l}0.00 * \\
(11.92\end{array}$ & $\begin{array}{l}-0.63^{*} \\
(-4.70)\end{array}$ & $\begin{array}{l}0.00^{*} \\
(9.29)\end{array}$ \\
\hline $\begin{array}{l}\text { (2) EMP } \\
\rightarrow \mathrm{KO} 1\end{array}$ & $\begin{array}{l}-0.05 \\
(-1.44)\end{array}$ & $\begin{array}{l}15.49^{*} \\
(9.11)\end{array}$ & $\begin{array}{c}-0.04 \\
(-1.12)\end{array}$ & $\begin{array}{l}43.23^{*} \\
(13.54)\end{array}$ & $\begin{array}{c}-0.07 \\
(-1.63)\end{array}$ & $\begin{array}{l}68.58^{*} \\
(9.82)\end{array}$ & $\begin{array}{l}-0.08 \\
(-1.61)\end{array}$ & $\begin{array}{l}61.82 * \\
(7.63)\end{array}$ \\
\hline $\begin{array}{l}(3) \mathrm{KO} 2 \\
\rightarrow \mathrm{EMP}\end{array}$ & $\begin{array}{l}-0.28^{*} \\
(-4.54)\end{array}$ & $\begin{array}{l}0.00 * \\
(9.80)\end{array}$ & $\begin{array}{l}-0.04 \\
-1.90\end{array}$ & $\begin{array}{l}0.00^{*} \\
6.22\end{array}$ & $\begin{array}{l}-0.59 * \\
(-5.23)\end{array}$ & $\begin{array}{l}0.00^{*} \\
10.60\end{array}$ & $\begin{array}{l}-0.48^{*} \\
(-4.24)\end{array}$ & $\begin{array}{c}0.00^{*} \\
8.23\end{array}$ \\
\hline $\begin{array}{l}\text { (4) EMP } \\
\rightarrow \mathrm{KO} 2\end{array}$ & $\begin{array}{l}-0.53^{*} \\
-6.45\end{array}$ & $\begin{array}{l}65.82^{*} \\
23.14\end{array}$ & $\begin{array}{l}-0.63^{*} \\
(-6.40)\end{array}$ & $\begin{array}{c}- \\
78.77^{*} \\
(19.50)\end{array}$ & $\begin{array}{c}-0.03 \\
(-0.81)\end{array}$ & $\begin{array}{l}43.84 * \\
(9.90)\end{array}$ & $\begin{array}{c}-0.17 \\
(-2.14)\end{array}$ & $\begin{array}{l}49.06^{*} \\
(10.01)\end{array}$ \\
\hline
\end{tabular}

Note: ${ }^{*}$ denotes statistical significance at the $1 \%$ level. Numbers in brackets are the estimated F-statistics and t-statistics for the coefficients $\delta$ and $\varphi$, respectively. $p$ denotes the lag length.

From the coefficients of the differenced explanatory variables, the magnitude and the direction of the causal relationship between the explained and the explanatory variables can be identified (Groenewold and Tang, 2007). On the other hand, the magnitude of the error correction term $\left(E C T_{t-1}\right)$ indicates the speed of adjustment from a short-run disequilibrium. The results obtained from the Granger causality tests based on VECM reported in Table 4 indicates that the tested hypotheses (1) and (3) are rejected at 1\% level with the signs of the coefficients in line with what the Sudden Stop theory suggests. These findings are generally consistent in different lag levels. An examination of the magnitude of the coefficients suggests that the causal effects are similar on both cases. The coefficients of the lagged error correction terms are also significant at the $1 \%$ level with a negative sign, which confirms the findings from the ARDL bounds test that there exists a long-run equilibrium relationship between EMP and the two proxies of capital outflows. In all three cases, the coefficient of the lagged error correction term is quite high, which suggests that convergence to the long-run equilibrium path following a shock is fast. Results indicate evidence of reverse causality only in the case of hypothesis (4) at lag levels 1 and 2.

\footnotetext{
${ }^{5}$ Results of the diagnostic tests are not reported to preserve space. However, they are available from the author upon request.
} 


\section{CONCLUSIONS}

There has been growing interest in the causal effects of capital reversals and EMP especially with the developments on the theoretical front. This article, for the first time, examined shortrun and long-run causal effect of capital reversals on exchange market pressure in Turkey. The results suggested that capital reversals and EMP are in a long-run equilibrium relationship and that, capital reversals Granger-cause EMP both in short-run and long-run. Overall, the findings lend support to the sudden stop hypothesis based on the case of Turkey. These results are also consistent with the findings of several earlier studies on the root causes of currency crises in Turkey such as Kibritcioglu et al. (1998), Gazioglu (2003) and Ghoshal (2006) who suggest that the currency crises in Turkey were, among other factors, a consequence of short-term capital movements. The policy implication that emerge from the analysis is clear: Practitioners and policy makers should closely monitor the capital movements for any sign of reversals, whereas governments should not rely on hot money in their long-term plans, particularly for financing deficits as any unanticipated reversal in capital flows would cause an increase in the exchange market pressure, the excess of which would result in a currency crisis.

\section{REFERENCES}

Alper, C. E. (2001) The Turkish Liquidity Crisis of 2000, Russian and East European Finance and Trade, 37, 58-80.

Alper, C. E. and Saglam, I. (2001) The Transmission of a Sudden Capital Outflow: Evidence from Turkey, Eastern European Economics, 29-48.

Atkins, F. J. and Serletis, A. (2003) Bounds Tests of the Gibson Paradox and the Fisher Effect: Evidence from Low Frequency International Data, The Manchester School, 71, 673679.

Bender, K. A., Neumann, R. M. and Skatun, J. D. (2006) Unemployment and Other Measures of Labor Market Inefficiency: A Comparison of U.K. and U.S. Labor Markets 1931-96, Economic Inquiry, 44, 629-643.

Berument, H. ; Nildag, B. C. and Olgun, H. (2007) The Effects of Changes in the Anticipated and Unanticipated Fed Funds Target Rate on Financial Indicators: The Case of an Emerging Market Country-Turkey, International Research Journal of Finance and Economics, Issue 7, 40-47.

Calvo, G. (1998) Capital Flows and Capital-Market Crises: The simple economics of Sudden Stops, Journal of Applied Economics, 1, 35-54.

Calvo, G; Izquierdo, A and E. Talvi (2003) Sudden Stops, the Real Exchange Rate and Fiscal Sustainability: Argentina's Lessons, Manuscript, IADB Research Department (July).

Ekinci, N. K. (2002) Anatomy of the Recent Crisis in Turkey, Journal of Economic Cooperation, 23, 15-28. 
Eichengeen, B., A. K. Rose and C. Wyposz (1995) Speculative Attacks on Pegged Exchange Rates: Exchange Market Mayhem: The Antecedents and Aftermath of Speculative Attacks, Economic Policy, 21, 251-296.

Gazioglu, S. (2003) Capital flows to an emerging financial market in Turkey, International Advances in Economic Research, 9, 175-188

Ghoshal, A. (2006) Anatomy of a currency crisis: Turkey 2000-2001, International Journal of Emerging Markets, 1, 176 - 189.

Groenewold, N. and Tang, S. H. K. (2007) Killing the goose that lays the golden egg: institutional change and Economic Growth in Hong Kong, Economic Inquiry, OnlineEarly Articles. Published article online: 22-Feb-2007

Kaminsky, G. L. and Reinhart, C. M. (1999) The Twin Crises: The Causes of Banking and Balance-Of-Payments Problems, The American Economic Review, 89, 473-500.

Katircioglu, S. (2009), Trade, Tourism and Growth: The Case of Cyprus, Applied Economics, 41, 2741-50.

Kibritcioglu, B; Kose, B and Ugur, G. (1998) A Leading Indicators Approach to the Predictability of Curreny Crises: The Case of Turkey, Hazine Dergisi, 12, 1-27.

Komulainen T., J. Lukkarila (2003) What Drives Financial Crises in Emerging Markets, Emerging Markets Review, 4, 248-272.

Morley, B. (2006) Causality between economic growth and immigration: An ARDL bounds testing approach, Economics Letters, 90, 72-76.

Narayan, P. K. and Smyth, R. (2004) The relationship between the real exchange rate and balance of payments: empirical evidence for China from co-integration and causality testing, Applied Economic Letters, 11, 287-291.

Narayan, P. K. and Smyth, R. (2005) Electricity Consumption, Employment and Real Income in Australia: Evidence from Multivariate Granger causality tests, Energy Policy, 33, 11091116.

Pesaran, M. H., Shin, Y., Smith, R.J. (2001) Bounds testing approaches to the analysis of level relationships, Journal of Applied Econometrics, 16, 289-326.

Saxena S. C. (2004) The Changing Nature of Currency Crises, Journal of Economic Surveys, $18,321-350$.

Yeldan, E. (1998) On Structural Sources of the 1994 Turkish Crisis: A CGE Modeling Analysis, The International Review of Applied Economics, 12, 397-414. 


\title{
Appendix I. Sources of Data Used in Estimations
}

\begin{tabular}{ll}
\hline Data & Source \\
M1 & IFS line 34 \\
M2 & IFS line 35LZF \\
$\begin{array}{l}\text { Real effective exchange rate } \\
\text { Turkish lira-Deutsche } \\
\text { exchange rate }\end{array}$ & CBRT \\
Turkish lira-euro exchange rate & CBRT \\
Turkish lira-US dollar exchange rate & CBRT \\
3-month deposit rate & CBRT \\
3-month US T-Bill rate & IFS line 60LZF \\
US M1 & IFS line 60CS \\
International reserves & IFS line 34 (interpolated from quarterly series) \\
US international reserves & IFS line 1LD \\
Bank Deposits & IFS line 1LD \\
Credits to Domestic Private Sector & IFS line 24+25 \\
Foreign Liabilities of Banks & IFS line 32DZF \\
\hline
\end{tabular}

Data Sources Key:

CBRT EDDS: The Central Bank of the Republic of Turkey Electronic Data Delivery System IFS: International Financial Statistics Database of the IMF

TT: The Undersecretariat of the Turkish Treasury Web Site (www.hazine.gov.tr)

\section{PAD VRIJEDNOSTI KAPITALA I PRITISAK TRŽIŠTA VALUTA: NALAZ GRANIČNOG TESTA AUTOREGRESIJSKOG MODELA S DISTRIBUIRANIM VREMENSKIM POMAKOM}

\begin{abstract}
SAŽETAK
Članak proučava vezu između pada vrijednosti kapitala i pritiska tržišta valuta u Turskoj u okviru graničnog testiranja autoregresijskog modela $s$ distribuiranim vremenskim pomakom (ARDL) $i$ Grangerove kauzalnosti uz pomoć mjesečnih podataka od 1991:12 do 2006:08. Rezultati pokazuju da se i kapitala nalaze u dugoročnoj ravnoteži s pritiskom valutnog tržišta. Granger testovi kauzalnosti ukazuju na to da postoji kratkoročna i dugoročna kauzalnost koja se kreće od pada vrijednosti kapitala u smjeru pritiska valutnog tržišta ali ne i obrnuto. Takav nalaz empirijski podupire teoriju naglog zastoja.
\end{abstract}

Ključne riječi: pad vrijednosti kapitala, pritisak valutnog tržišta, Turska, ARDL (autoregresijski model s distribuiranim vremenskim pomakom) 